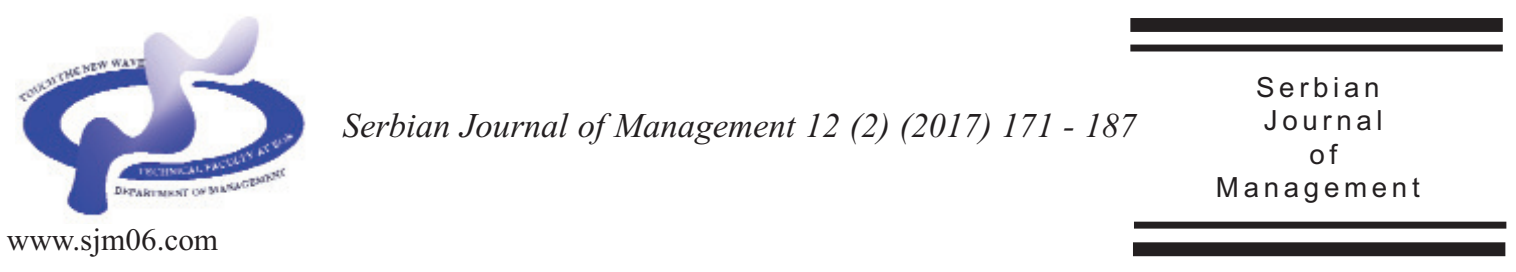

\title{
THE UNIVERSITY OF BELGRADE ON ARWU LIST - PART I: THE IMPACT OF INDIVIDUAL FACULTIES ON THE ACHIEVED POSITION USING PROMETHEE-GAIA METHOD
}

\author{
Živan Živković, Milica Arsić* and Đorđe Nikolić \\ University of Belgrade, Technical Faculty in Bor, Engineering Management Department, \\ Vojske Jugoslavije 12, 19210 Bor, Serbia \\ (Received 28 March 2017; accepted 10 June 2017)
}

\begin{abstract}
Since 2012, University of Belgrade (UB) has been ranked among the 500 best universities in the world on the prestigious Academic Ranking of World Universities (ARWU) list, also known as Shanghai list. These top 500 universities represent only $2 \%$ of all universities in the world. According to the most recent global ranking done in 2015, UB ranks between 201 and 300 place, and is the best ranked university in Southeast Europe.

UB consists of 31 faculties and 11 research institutes and each of these institutions in its own way contributes to the overall achieved position of UB on the ARWU list. This paper analyzes the impact of its certain faculties on the UB's ranking position through a number of papers indexed in Science Citation Index - SCIe and SSCI, the number of citations and the number of citations per paper and per researcher for the period 2011 - 2015. For data processing multi-criteria decision making method PROMETHEE-GAIA, was used. Obtained results revealed four clusters of faculties such as faculties - with the greatest impact, with a significant impact, medium and low impact on the overall ranking result on ARWU list.
\end{abstract}

Keywords: Ranking of faculties, University of Belgrade, ARWU list, PROMETHEE - GAIA method

\section{INTRODUCTION}

By definition, expert knowledge has been generated at faculties of prestigious universities in the world (Brew \& Boud, 1995; Millot, 2015). There are four types of knowledge that define the quality characteristics of higher education institutions: internal and external, tacit and implicit knowledge reflected in the quality of teaching staff, internal resources, databases, textbooks, expertise and other things in a

\footnotetext{
*Corresponding author: marsic@tfbor.bg.ac.rs
}

DOI: $10.5937 / \mathrm{sjm} 12-13562$ 
changing environment with growing requirements for continuous increase of the quality of their output (Wijetunge, 2002; Arsić et al., 2012). The quality of knowledge generated in higher education institutions is a reflection of the quality of scientific work which is measured by the number of publications and citations in refereed journals (Price \& Cotton, 2006; Abramo et al., 2013; Metcalf et al., 2015; Saarela et al., 2016).

Ranking of universities has become extremely popular at the beginning of the 21 st century and has been widely accepted as a measure of their success (Millot, 2015) There are global, regional and national rankings of higher education institutions and universities (Arsić et al., 2012; Altanopoulou et al., 2012; Chou et al., 2013; Da Silva et al., 2016). Most popular lists of university ranking in the world are (Sidorenko \& Gorbatova, 2015; Millot, 2015; Olcay \& Bulu, 2016):

- QS World University Rankings (published since 2000);

- Academic Ranking of World Universities (ARWU), Shanghai Ranking (published since 2003);

- Times Higher Education World University Ranking - Thomson Reuters (THE) (published since 2010) etc.

Ranking criteria for these lists, as well as for some other lists are: quality of teaching, quality of research, citation, quality of education, quality of a faculty, international outlook, industry income and other (Docampo, 2013; Olcay \& Bulu, 2016), although with respect to the ranking results, there may be some shortcomings, such as the size of the university or scientific field, due to different possibility for publishing (Lin et al., 2013; Daraio et.al., 2015). The most popular and most commonly used for comparison of individual institutions is ARWU list also known as the Shanghai list published by Shanghai Cijao Tong University once a year, since 2003.

ARWU ranking list every year presents the best 500 universities in the world. The top 100 universities are ranked, and the remaining 400 are arranged by alphabetical order into four clusters, each cluster consisting of 100 universities. Since ARWU list includes less than $2 \%$ of all universities it is considered the best quality indicator of the university (Zornić et al., 2014).

The ranking is done according to the following criteria of the quality of education: (a) the number of graduates who are winners of the Nobel Prize and Medal in scientific fields (Alumni) - 10\%; (b) -quality of the faculty: the number of employees who won the Nobel Prize or Medals in scientific fields (Award) - 20\%; (c) - number of highly cited scientists from 21 scientific fields (HiCi) $20 \%$; (d) - results of scientific research: number of papers published in the journals Nature and Science (N\&S) - 20\%; (e)number of papers published in SCIe and SSCI journals (PUB)- 20\%; (f) - Per capita academic performance of an institution (PCP)- 10\% (Docampo, 2013; Olcay \& Bulu, 2016).

From South-East Europe on the ARWU list in 2015 are only the following universities: University of Belgrade (Serbia) in the cluster 201-300; the University of Ljubljana (Slovenia) in the cluster 401-500 and Eötvös Lorand University and the University of Szeged (Hungary), also in a cluster 401-500.

The University of Belgrade, Serbia (UB) first time appeared on ARWU list in 2012, in a cluster 401-500 where it also stayed in 2013. In 2014, UB moved to a cluster 301400 and currently is in cluster 201-300. 
Position of UB on ARWU list is a result of scientific work at 31 faculties and 11 institutes. From these criteria, approximately $50 \%$ belong to the number of papers published in journals on SCIe and SSCI lists, the number of citations and the number of results per researcher which has a predominant influence on the position of UB on ARWU list (Zornić et al., 2014).

\section{EXPERIMENTAL (RESEARCH)}

This paper presents the results of ranking of the UB's faculties by following criteria: number of papers published in journals on SCIe and SSCI lists per researcher as well as the number of citations per published work and researcher at each faculty. Faculties are grouped in four scientific fields: (1) Social Sciences and Humanities, (2) Medical Sciences, (3) Science and Mathematics and (4) Technology and Engineering Sciences (Please see Table 1).

Data on the number and titles of the faculties' staff were taken from the official website of the University. A search of academic databases Scopus (www.scopus.com) came up to the data that these researchers published 19023 scientific papers in period $(2011-2015$.), and that in this five-year period, their papers were cited 36579 times. Also, it should be emphasized that only papers published in scientific journals on SCI and JCR lists were discussed. Papers from seminars and conferences are not included. Also, as for the citations, self-citations are not included. It should be noted that this search of Scopus database was conducted in January 2016, and these results, presented in the paper, correspond to the data for that period.

\subsection{Structure of $U B$}

UB is the oldest and the largest university in Serbia. It was founded in 1808. Today the UB consists of 31 independent faculties and 11 research institutes. More than 4000 professors and teaching assistants are employed and over 80000 students are studying at UB. Regarding the scientific fields which it covers and achieved results in education and scientific research UB is an institution of great national importance and it represents a national brand in Serbia. Table 1 presents the number and structure of employees at UB faculties, at the end of 2015.

\section{RESULTS}

\subsection{Papers published in journals indexed in SCIe and SSCI}

Since 2005, with introduction of standards for accreditation of faculties and universities in Serbia, criteria for promotion of teachers and scientists as well as the formal application for defense of the doctoral dissertation, the predominant requirements for all these activities are scientific papers published in journals on Thomson Reuters SCIe, SSCI and ARTS \& HUMANITIES lists. This requirement has contributed that teachers at universities and scientists in institutes started to publish their work in journals on the above mentioned list, which brought UB in 2012 on ARWU list, and it has maintained its position to this day.

Papers published in journals on SCIe and SSCI list are not always a reliable indicator of the quality of scientific research because of the problematic quality of certain journals. Among these journals there are those who 
Table 1. Number and structure of employees for each faculty in 2015.

\begin{tabular}{lccccc}
\hline Faculty & $\begin{array}{c}\text { Full } \\
\text { professor }\end{array}$ & $\begin{array}{c}\text { Associate } \\
\text { professor }\end{array}$ & $\begin{array}{c}\text { Assistant } \\
\text { professor }\end{array}$ & $\begin{array}{c}\text { Teaching } \\
\text { assistant }\end{array}$ & Total \\
\hline Social sciences and humanities & & & & & \\
Faculty for Special Education and Rehabilitation - FSER & 34 & 16 & 11 & 32 & 93 \\
Faculty of Philology - FP & 53 & 43 & 63 & 58 & 217 \\
Teacher Education Faculty - TEF & 16 & 9 & 23 & 15 & 63 \\
Faculty of Economics - FE & 36 & 25 & 23 & 28 & 112 \\
Faculty of Philosophy - FPhy & 80 & 71 & 98 & 21 & 270 \\
Faculty of Low - FL & 36 & 20 & 28 & 20 & 104 \\
Faculty of Security Studies - FSS & 12 & 9 & 10 & 9 & 40 \\
Faculty of Sport and Physical Education - FSPE & 17 & 14 & 15 & 15 & 61 \\
Faculty of Orthodox Theology - FOT & 11 & 12 & 15 & 11 & 49 \\
Faculty of Political Sciences - FPS & 38 & 14 & 20 & 27 & 99 \\
Medical sciences & & & & & \\
Faculty of Medicine - FM & 68 & 63 & 58 & 65 & 254 \\
Faculty of Pharmacy - FPh & 47 & 23 & 40 & 34 & 144 \\
Faculty of Dental Medicine - FDM & 45 & 16 & 34 & 0 & 95 \\
Faculty of Vetenary Medicine - FVM & 38 & 28 & 29 & 32 & 127 \\
Science and mathematics & & & & & \\
Faculty of Biology - FB & 25 & 36 & 42 & 12 & 115 \\
Faculty of Mathematics - FMath & 17 & 14 & 27 & 53 & 111 \\
Faculty of Geography - FGeo & 19 & 9 & 25 & 11 & 64 \\
Faculty of Chemistry - FCh & 19 & 14 & 20 & 20 & 73 \\
Faculty of Physics - FPhys & 19 & 17 & 18 & 5 & 59 \\
Faculty of Physical Chemistry - FPhyChe & 9 & 8 & 10 & 14 & 41 \\
Technology and engineering sciences & & & & & \\
Faculty of Civil Engineering - FCEng & 18 & 25 & 50 & 65 & 158 \\
Faculty of Agriculture - FAg & 97 & 44 & 73 & 47 & 261 \\
Faculty of Mechanical Engineering - FMEng & 77 & 33 & 49 & 55 & 214 \\
Faculty of Technology and Metallurgy - FTM & 51 & 31 & 31 & 39 & 152 \\
Faculty of Organizational Sciences - FOS & 41 & 24 & 39 & 58 & 162 \\
Faculty of Electrical Engineering - FEENG & 51 & 28 & 44 & 40 & 163 \\
Faculty of Architecture - FAr & 18 & 26 & 36 & 40 & 120 \\
Technical Faculty in Bor - TFB & 20 & 17 & 26 & 18 & 81 \\
Faculty of Forestry - FF & 38 & 18 & 32 & 17 & 105 \\
Faculty of Transport and Traffic Engineering - FTTEng & 32 & 17 & 53 & 40 & 142 \\
Faculty of Mining and Geology - FMG & 42 & 31 & 23 & 14 & 110 \\
\hline
\end{tabular}

charge fees for publishing regardless the quality of submitted papers. The consequences of such a policy were that these journals lost their impact factor (IF) and received the status of predatory journals (TTEM, Metalurgia International, HOLTMED, etc.). Also, there is a practice of "mutual agreement" to list co-authors on scientific papers who did not contributed in a research process at all, and there are frequent cases that co-authors are not even familiar with that particular scientific field. Singleauthor papers are very rare, so sometimes it is very difficult to determine the right number of publications in a single institution. Therefore, expressing the number of published papers per researcher employed at the institution (faculty) represents a more objective picture on the volume of published papers in that institution (faculty) and its impact on the overall rating of the university whom it belongs. 
Figure 1 shows the trend of published works at UB for all four field groups for the period 2011 - 2015 as well as the number of papers per researcher for each year. This method gives us the opportunity to compare the results by fields of science, which are very different in methodology and scope of research, possibilities for publishing and overall achieved level of development of scientific research work.

The obtained results indicate that the quality of work by the number of published papers per researcher criterion is the lowest in the field of social sciences and humanities, than, in ascending order, it is followed by faculties in the field of technology and engineering sciences and medical sciences whereas the best results were achieved in the field of science and mathematics. In the field of SM (Figure 3) the best result have achieved FCh and FPhyChe, in the field of

a)

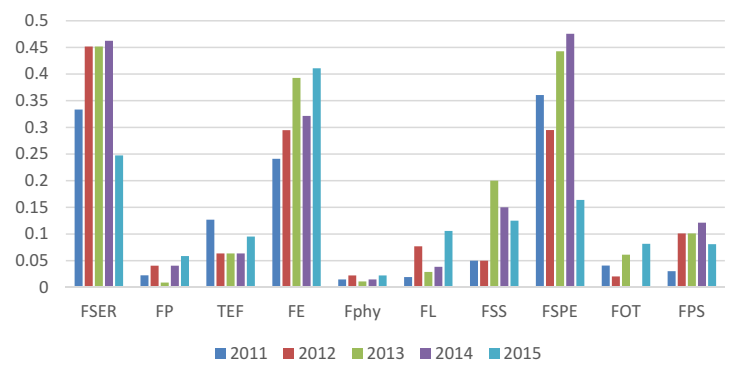

c)

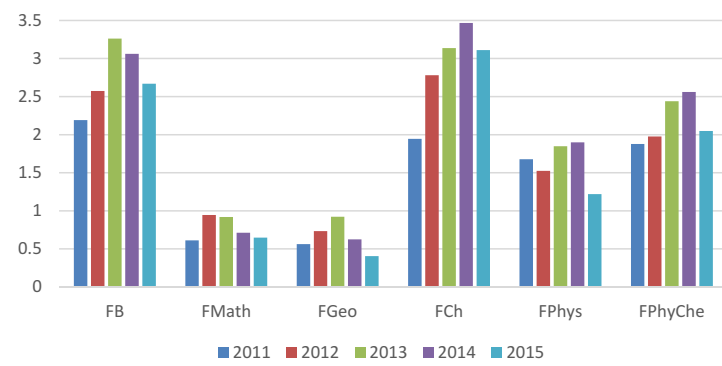

MS - FM and FPh, in the field of TES, FTM, and in the field of SSH - FSPE, FE and FSER.

Ascending trend in the number of publications in journals on SCIe and SSCI lists in the period 2011-2015 is the most evident at faculties: FSPE, FM, FPh and FTM.

Ranking of individual faculties by the criterion number of papers per researcher in journals on SCIe and SSCI lists for the period 2011-2015, is shown in Table 2. The impact of this criterion can be expressed in three clusters regarding the number of papers per researcher greater than 10 (a major impact - A cluster) in the range 5 - 10 (medium impact- Cluster B), and in the range 0-5 (low impact - Cluster C), Cutting point for clusters are chosen by authors themselves, and are only there to give more clear presentation regarding the number of

b)

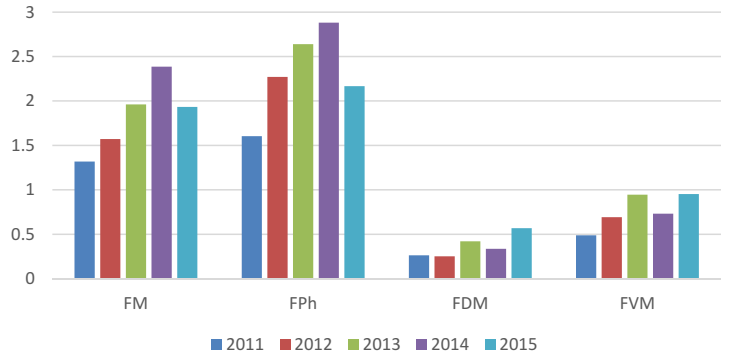

d)

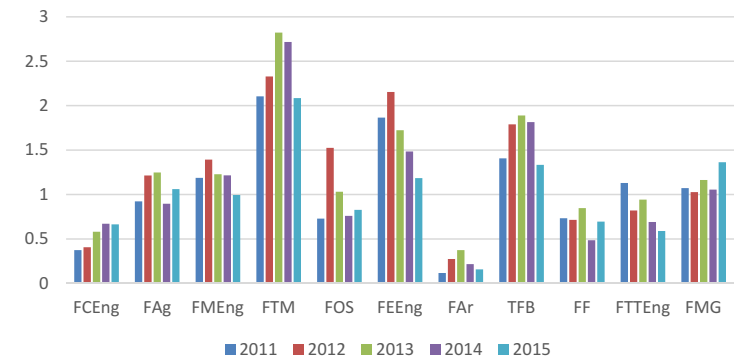

Figure 1. The number of papers per researcher for the group of faculties: a) within Social Sciences and Humanities; b) within Medical Sciences; c) within Science and Mathematics; d) within Technology and Engineering Sciences 
Table 2. Ranking of individual faculties by the criterion number of papers per researcher for the period 2011-2015.

\begin{tabular}{|c|c|c|c|}
\hline Faculty & $\begin{array}{c}\text { Number of } \\
\text { papers/number } \\
\text { of researchers }\end{array}$ & Cluster & $\begin{array}{c}\text { Scientific } \\
\text { field }\end{array}$ \\
\hline Faculty of Chemistry - FCh & 15.04 & \multirow{5}{*}{ A } & SM \\
\hline Faculty of Biology - FB & 13.00 & & SM \\
\hline Faculty of Physical Chemistry - FPhyChe & 11.68 & & $\mathrm{SM}$ \\
\hline Faculty of Technology and Metallurgy - FTM & 11.48 & & TES \\
\hline Faculty of Pharmacy - FPh & 11.41 & & MS \\
\hline Faculty of Agriculture - FAg & 9.28 & \multirow{9}{*}{ B } & TES \\
\hline Faculty of Medicine - FM & 9.19 & & MS \\
\hline Faculty of Electrical Engineering - FEENG & 8.73 & & TES \\
\hline Technical Faculty in Bor - TFB & 8.27 & & TES \\
\hline Faculty of Physics - FPhys & 7.31 & & $\mathrm{SM}$ \\
\hline Faculty of Transport and Traffic Engineering - FTTEng & 6.25 & & SM \\
\hline Faculty of Mechanical Engineering - FMEng & 5.83 & & TES \\
\hline Faculty of Organizational Sciences - FOS & 5.38 & & TES \\
\hline Faculty of Mathematics - FMath & 5.36 & & SM \\
\hline Faculty of Mining and Geology - FMG & 4.88 & \multirow{17}{*}{$\mathrm{C}$} & TES \\
\hline Faculty of Vetenary Medicine - FVM & 3.78 & & MS \\
\hline Faculty of Forestry - FF & 3.31 & & TES \\
\hline Faculty of Civil Engineering - FCEng & 3.27 & & TES \\
\hline Faculty of Geography - FGeo & 3.25 & & SM \\
\hline Faculty of Dental Medicine -FDM & 2.19 & & MS \\
\hline Faculty for Special Education and Rehabilitation - FSER & 2.03 & & SSH \\
\hline Faculty of Sport and Physical Education - FSPE & 1.76 & & $\mathrm{SSH}$ \\
\hline Faculty of Economics - FE & 1.56 & & SSH \\
\hline Faculty of Architecture - FAr & 1.19 & & TES \\
\hline Faculty of Security Studies - FSS & 0.55 & & SSH \\
\hline Faculty of Political Sciences - FPS & 0.49 & & SSH \\
\hline Teacher Education Faculty - TEF & 0.38 & & SSH \\
\hline Faculty of Low - FL & 0.25 & & SSH \\
\hline Faculty of Orthodox Theology - FOT & 0.21 & & SSH \\
\hline Faculty of Philology - FP & 0.17 & & SSH \\
\hline Faculty of Philosophy - FPhy & 0.06 & & SSH \\
\hline
\end{tabular}

papers per researcher at different faculties. The real ranking was done at the end of the paper, using PROMETHEE-GAIA methodology.

\subsection{The impact of number of citations}

A paper published in a journal on SCIe and SSCI lists is necessary, but not sufficient requirement in order to be able to give a reliable assessment of the quality of that published work and its impact on the rating of the faculty which author wrote as his affiliation. If the published work does not cause any reaction of the scientific community through citation in journals on Thomson Reuters list, then the quality of such papers cannot be highly appreciated. In this study the number of citations was determined based on the Scopus database which does not give a complete and reliable information but with a high probability defines the order of ranking. Figure 2 shows the results of the number of citations per researcher for each faculty within UB for the period 2011-2015. It must be emphasized 
that here only citations of papers published in 2011 and later are presented.

The obtained results shown in Figure 2 present a descending trend of citations after 2012-2013, which indicates that the quality of published papers at most faculties decline. Having in mind that only citations of papers published in 2011 and later were considered in this study, it must be clear that the number of citations will be larger if citations of all papers were included.

Table 3 shows the ranking list of faculties according the number of citations per researcher for the period 2011-2015 criterion. Faculties are divided into three clusters in terms of the number of citations per researcher greater than 10 (major impact - A cluster) in the range 5 - 10 (medium impact- Cluster B) and in the range 0-5 citation (low impact - Cluster C).

a)

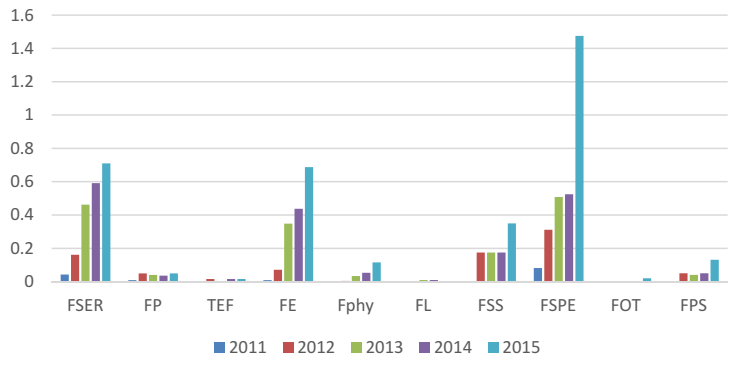

c)

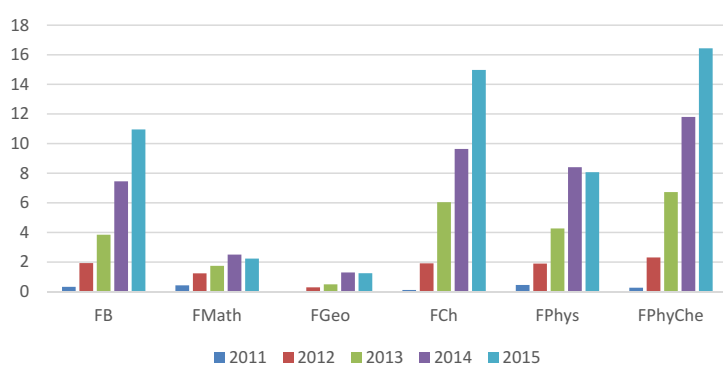

3.3. The impact of ratio number of citations and number of papers per researcher

The criterion number of citations per published paper and per researcher can be one of the most suitable criteria for assessing the overall quality of scientific research at the university. Table 4 shows the results of ranking the UB faculties by the number of citations per published paper and researcher criterion.

In summary, the impact of individual faculties of UB by criteria the number of published papers, the number of citations and the number of citations per published paper per professors and assistants employed at faculties, is shown in Figure 3. According to this figure we can identify four clusters of influence:

b)

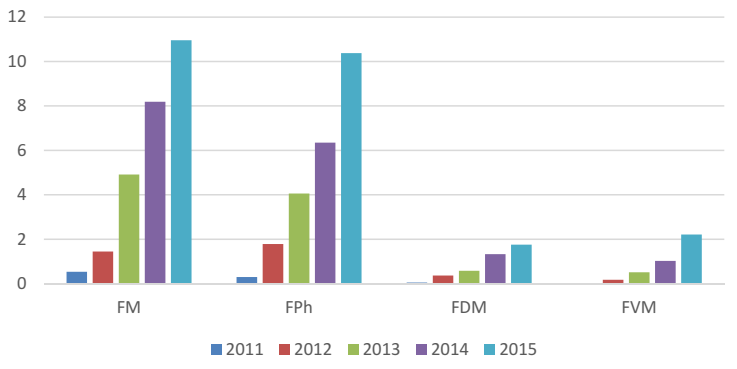

d)

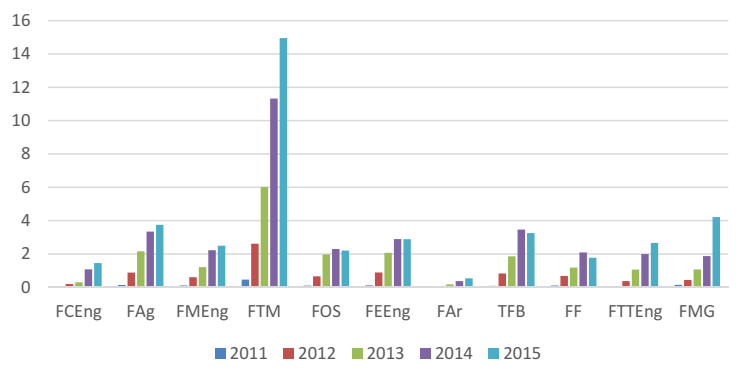

Figure 2. The number of citations per researcher for the group of faculties a) within Social Sciences and Humanities; b) within Medical Sciences; c) within Science and Mathematics; d) within Technology and Engineering Sciences 
Table 3. Ranking of individual faculties by the number of citations per researcher in period 2011-2015 criterion

\begin{tabular}{|c|c|c|c|}
\hline Faculty & $\begin{array}{c}\text { Number of } \\
\text { citations/numbe } \\
\mathbf{r} \text { of researchers }\end{array}$ & Cluster & $\begin{array}{c}\text { Scientific } \\
\text { field }\end{array}$ \\
\hline Faculty of Physical Chemistry - FPhyChe & 39.93 & \multirow{8}{*}{ A } & $\mathrm{SM}$ \\
\hline Faculty of Chemistry - FCh & 33.56 & & SM \\
\hline Faculty of Technology and Metallurgy - FTM & 33.36 & & TES \\
\hline Faculty of Medicine - FM & 25.97 & & MS \\
\hline Faculty of Biology - FB & 23.54 & & SM \\
\hline Faculty of Pharmacy - FPh & 22.19 & & MS \\
\hline Faculty of Physics - FPhys & 20.87 & & SM \\
\hline Faculty of Mathematics - FMath & 12.58 & & $\mathrm{SM}$ \\
\hline Technical Faculty in Bor - TFB & 9.44 & \multirow{6}{*}{$\mathrm{B}$} & TES \\
\hline Faculty of Electrical Engineering - FEENG & 9.05 & & TES \\
\hline Faculty of Organizational Sciences - FOS & 8.56 & & TES \\
\hline Faculty of Mechanical Engineering - FMEng & 6.34 & & TES \\
\hline Faculty of Mining and Geology - FMG & 6.34 & & TES \\
\hline Faculty of Forestry - FF & 5.08 & & TES \\
\hline Faculty of Agriculture - FAg & 4.95 & \multirow{17}{*}{$\mathrm{C}$} & TES \\
\hline Faculty of Transport and Traffic Engineering - FTTEng & 4.68 & & TES \\
\hline Faculty of Vetenary Medicine - FVM & 3.84 & & MS \\
\hline Faculty of Civil Engineering - FCEng & 3.69 & & TES \\
\hline Faculty of Geography - FGeo & 3.10 & & SM \\
\hline Faculty of Sport and Physical Education - FSPE & 2.98 & & SSH \\
\hline Faculty for Special Education and Rehabilitation - FSER & 1.72 & & SSH \\
\hline Faculty of Economics - FE & 1.44 & & SSH \\
\hline Faculty of Architecture - FAr & 1.14 & & TES \\
\hline Faculty of Dental Medicine -FDM & 0.98 & & MS \\
\hline Faculty of Security Studies - FSS & 0.74 & & $\mathrm{SSH}$ \\
\hline Faculty of Political Sciences - FPS & 0.19 & & $\mathrm{SSH}$ \\
\hline Faculty of Philosophy - FPhy & 0.18 & & SSH \\
\hline Faculty of Philology - FP & 0.11 & & SSH \\
\hline Teacher Education Faculty - TEF & 0.05 & & SSH \\
\hline Faculty of Low - FL & 0.02 & & SSH \\
\hline Faculty of Orthodox Theology - FOT & 0.02 & & $\mathrm{SSH}$ \\
\hline
\end{tabular}

a) Cluster 1 - the cluster of great impact: FphyChe, FB, FCh, FTM, FPh, FM and FPhys.

b) Cluster 2 - the cluster of significant impact: FMath, FOS, FMG, FMEng, TFB, FEEng, FTTEng and FAg.

c) Cluster 3 - the cluster of medium impact: FP, FSPE, FF, FSS, FCEng, FVM, FPhy, FAr, FE, FSER and FGeo.

d) Cluster 4 - the cluster of low impact: FDM, FPS, TEF, FOT and FL.

\subsection{Evaluating the importance of each faculty by multi-criteria model}

In order to evaluate and rank the partial contribution of each faculty on the position of UB on ARWU list, the following three indicators with their importance weights in multi-criteria model were used:

1) The number of published papers in journals index in SCIe and SSCI per researcher $-20 \%$ 
Table 4. Ranking of impact of individual faculties by number of citation and number of papers per researcher criterion

\begin{tabular}{|c|c|c|c|}
\hline Faculty & $\begin{array}{c}\text { Number of } \\
\text { citations/numbe } \\
\text { r of papers }\end{array}$ & Cluster & $\begin{array}{c}\text { Scientific } \\
\text { field }\end{array}$ \\
\hline Faculty of Physical Chemistry - FPhyChe & 3.41 & \multirow{12}{*}{ A } & SM \\
\hline Faculty of Technology and Metallurgy - FTM & 2.90 & & TES \\
\hline Faculty of Physics - FPhys & 2.85 & & SM \\
\hline Faculty of Medicine - FM & 2.82 & & MS \\
\hline Faculty of Mathematics - FMath & 2.34 & & SM \\
\hline Faculty of Chemistry - FCh & 2.23 & & SM \\
\hline Faculty of Pharmacy - FPh & 1.94 & & MS \\
\hline Faculty of Biology - FB & 1.81 & & SM \\
\hline Faculty of Philosophy - FPhy & 1.73 & & SSH \\
\hline Faculty of Sport and Physical Education - FSPE & 1.69 & & SSH \\
\hline Faculty of Organizational Sciences - FOS & 1.59 & & TES \\
\hline Faculty of Forestry - FF & 1.53 & & TES \\
\hline Faculty of Security Studies - FSS & 1.36 & \multirow{8}{*}{ B } & $\mathrm{SSH}$ \\
\hline Faculty of Mining and Geology - FMG & 1.30 & & TES \\
\hline Technical Faculty in Bor - TFB & 1.14 & & TES \\
\hline Faculty of Civil Engineering - FCEng & 1.12 & & TES \\
\hline Faculty of Mechanical Engineering - FMEng & 1.08 & & TES \\
\hline Faculty of Philology - FP & 1.06 & & $\mathrm{SSH}$ \\
\hline Faculty of Electrical Engineering - FEENG & 1.03 & & TES \\
\hline Faculty of Vetenary Medicine - FVM & 1.01 & & MS \\
\hline Faculty of Geography - FGeo & 0.95 & \multirow{11}{*}{$\mathrm{C}$} & SM \\
\hline Faculty of Architecture - FAr & 0.95 & & TES \\
\hline Faculty of Economics - FE & 0.92 & & SSH \\
\hline Faculty for Special Education and Rehabilitation - FSER & 0.84 & & SSH \\
\hline Faculty of Transport and Traffic Engineering - FTTEng & 0.74 & & TES \\
\hline Faculty of Agriculture - FAg & 0.53 & & TES \\
\hline Faculty of Dental Medicine -FDM & 0.44 & & MS \\
\hline Faculty of Political Sciences - FPS & 0.38 & & SSH \\
\hline Teacher Education Faculty - TEF & 0.12 & & $\mathrm{SSH}$ \\
\hline Faculty of Orthodox Theology - FOT & 0.09 & & $\mathrm{SSH}$ \\
\hline Faculty of Low - FL & 0.06 & & SSH \\
\hline
\end{tabular}

2) The number of citations per researcher, according to SCOPUS database $30 \%$ and

3) The number of citations per published paper and researcher $-50 \%$.

Based on the data for quality indicators of scientific research at 31 faculties of UB in the period 2011 - 2015, an initial table for the evaluation and ranking of the impact of these faculties using PROMETHEE / GAIA methodology was created (Brans et al., 1984; Brans \& Vincke, 1985). This well-known multi-criteria methodology was applied in this study because of its advantages, which are primarily reflected in the way of structuring the problem, the amount of data that can be processed, ability to quantify qualitative values, good software support 


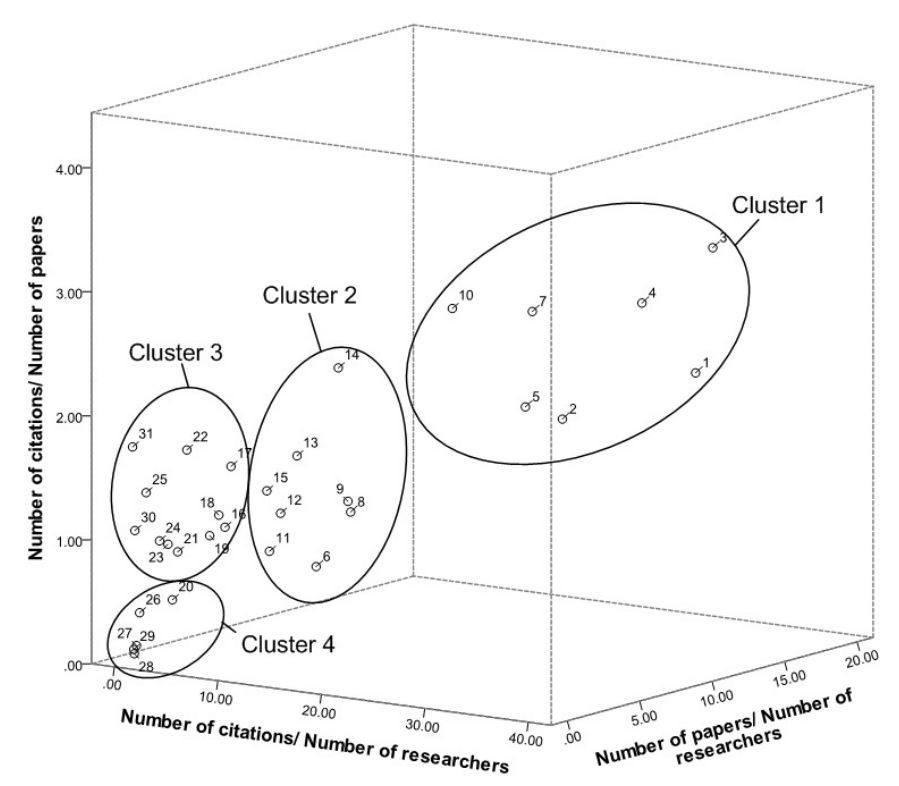

Legend: 1 - FPh; 2 - BF; 3 - FPhyChe; 4 - FTM; 5 - FPh; 6 - FAg; 7 - FM; 8 - FEEng;

9 - TFB; 10 - FPhys; 11 - FTTEng; 12 - FMEng; 13 - FOS; 14 - FMath; 15 - FMG; 16 - FVM;

17 -FF; 18 - FCEng; 19 - FGeo; 20 -FDM; 21 - FSER; 22 - FSPE; 23 - FE; 24 - FAr;

25 -FSS; 26 - FPS; 27 - TEF; 28 - FL; 29 - TOS; 30 - FP; 31 - FPhy.

Figure 3. The impact of individual faculties by the following criteria: the number of papers, the number of citations and the ratio number of citations and number of papers per researcher

and graphical presentation of the results on GAIA plane (Macharis et al., 2004; Behzadian et al., 2010).

Detailed procedures of PROMETHEE II methodology, which was used in this study, is described in the literature (Ishizaka \& Nemery, 2011).

For the data presented in Table 5, the initial parameters necessary for the implementation of PROMETHEE II complete ranking were defined, whereby for all three criteria, in multicriteria model,. Vshape function of preferences with preference threshold $\mathrm{p}=100 \%$, was selected (Vego et al., 2008).

Also, authors defined the percentage of importance of each of the criteria in the model, where the greatest importance, $50 \%$, was given to ratio (criteria 3-C3) the number of citations / number of papers, while the remaining $50 \%$ was distributed to the other two criteria $\mathrm{C} 1$ and $\mathrm{C} 2$ with the percentage of importance $30 \%$ and $20 \%$, respectively.

Based on the initial table for faculty evaluation, positive $(\varphi+)$ and negative flow of preferences $(\varphi-)$ were determined as well as the value of net flows $(\varphi)$ for each faculty, respectively. Results of PROMETHEE II rankings are shown in Table 6.

Based on the results shown in Table 6, the first group of 8 faculties can be extracted, which has high levels of net flows ( $\varphi$ value greater than 0.5), and top-ranked among them is the Faculty of Physical Chemistry from the group of Sciences and Mathematics with the value of the net-flow of preferences 0.8590 . Furthermore, it can be concluded that in this group the best ranked 5 out of 8 faculties are the faculties from SM group. In addition, in this first group there are also two faculties from group of Medical Sciences (FM and FPh) as well as very high-ranked 
Table 5. The initial table for evaluation of 31 faculties of $U B$

\begin{tabular}{|c|c|c|c|c|c|c|}
\hline No. & Name of faculty & $\begin{array}{c}\text { Faculty label in } \\
\text { PROMETHEE } \\
\text { model }\end{array}$ & $\begin{array}{c}\text { Scientific } \\
\text { field }^{*}\end{array}$ & $\begin{array}{l}\text { C1-Number of } \\
\text { papers/number } \\
\text { of researchers }\end{array}$ & $\begin{array}{c}\text { Criterion } \\
\text { C2- Number of } \\
\text { citations/number } \\
\text { of researchers }\end{array}$ & $\begin{array}{c}\text { C3-Number of } \\
\text { citations/number } \\
\text { of papers }\end{array}$ \\
\hline 1. & Faculty of Chemistry & Fac_1 & SM & 15.04 & 33.56 & 2.23 \\
\hline 2. & Faculty of Biology & Fac_2 & SM & 13.00 & 23.54 & 1.81 \\
\hline 3. & $\begin{array}{l}\text { Faculty of Physical } \\
\text { Chemistry }\end{array}$ & Fac_3 & SM & 11.68 & 39.93 & 3.42 \\
\hline 4. & $\begin{array}{l}\text { Faculty of Technology } \\
\text { and Metallurgy }\end{array}$ & Fac_4 & TES & 11.48 & 33.36 & 2.91 \\
\hline 5. & Faculty of Pharmacy & Fac_5 & MS & 11.41 & 22.19 & 1.95 \\
\hline 6. & Faculty of Agriculture & Fac_6 & TES & 9.28 & 4.95 & 0.53 \\
\hline 7. & Faculty of Medicine & Fac_7 & MS & 9.19 & 25.97 & 2.83 \\
\hline 8. & $\begin{array}{l}\text { Faculty of Electrical } \\
\text { Engineering }\end{array}$ & Fac_8 & TES & 8.73 & 9.05 & 1.04 \\
\hline 9. & Technical Faculty in Bor & Fac_9 & TES & 8.27 & 9.44 & 1.14 \\
\hline 10. & Faculty of Physics & Fac_10 & SM & 7.31 & 20.87 & 2.86 \\
\hline 11. & $\begin{array}{l}\text { Faculty of Transport and } \\
\text { Traffic Engineering }\end{array}$ & Fac_11 & TES & 6.25 & 4.68 & 0.75 \\
\hline 12. & $\begin{array}{l}\text { Faculty of Mechanical } \\
\text { Engineering }\end{array}$ & Fac_12 & TES & 5.83 & 6.34 & 1.09 \\
\hline 13. & $\begin{array}{l}\text { Faculty of Organizational } \\
\text { Sciences }\end{array}$ & Fac_13 & TES & 5.38 & 8.56 & 1.59 \\
\hline 14. & Faculty of Mathematics & Fac_14 & SM & 5.36 & 12.58 & 2.35 \\
\hline 15. & $\begin{array}{l}\text { Faculty of Mining and } \\
\text { Geology }\end{array}$ & Fac_15 & TES & 4.88 & 6.34 & 1.30 \\
\hline 16. & $\begin{array}{l}\text { Faculty of Veterinary } \\
\text { Medicine }\end{array}$ & Fac_16 & MS & 3.78 & 3.84 & 1.01 \\
\hline 17. & Faculty of Forestry & Fac_17 & TES & 3.31 & 5.08 & 1.53 \\
\hline 18. & $\begin{array}{l}\text { Faculty of Civil } \\
\text { Engineering }\end{array}$ & Fac_18 & TES & 3.27 & 3.69 & 1.13 \\
\hline 19. & Faculty of Geography & Fac_19 & SM & 3.25 & 3.10 & 0.95 \\
\hline 20. & $\begin{array}{l}\text { Faculty of Dental } \\
\text { Medicine }\end{array}$ & Fac_20 & MS & 2.19 & 0.98 & 0.45 \\
\hline 21. & $\begin{array}{l}\text { Faculty for Special } \\
\text { Education and } \\
\text { Rehabilitation }\end{array}$ & Fac $\_21$ & SSH & 2.03 & 1.72 & 0.85 \\
\hline 22. & $\begin{array}{l}\text { Faculty of Sport and } \\
\text { Physical Education }\end{array}$ & Fac_22 & SSH & 1.76 & 2.98 & 1.69 \\
\hline $\begin{array}{l}23 . \\
24 .\end{array}$ & $\begin{array}{l}\text { Faculty of Economics } \\
\text { Faculty }\end{array}$ & Fac_23 & SSH & 1.56 & 1.44 & 0.92 \\
\hline $\begin{array}{l}24 . \\
25 .\end{array}$ & $\begin{array}{l}\text { Faculty of Architecture } \\
\text { Faculty of Security } \\
\text { Studies }\end{array}$ & Fac_25 & SSH & 0.55 & 0.74 & 1.36 \\
\hline 26. & $\begin{array}{l}\text { Faculty of Political } \\
\text { Sciences }\end{array}$ & Fac_26 & SSH & 0.49 & 0.19 & 0.39 \\
\hline 27. & $\begin{array}{l}\text { Teacher Education } \\
\text { Faculty }\end{array}$ & Fac_27 & SSH & 0.38 & 0.05 & 0.12 \\
\hline 28. & Faculty of Low & Fac_28 & SSH & 0.25 & 0.02 & 0.06 \\
\hline 29. & $\begin{array}{l}\text { Faculty of Orthodox } \\
\text { Theology }\end{array}$ & Fac $\_29$ & SSH & 0.21 & 0.02 & 0.10 \\
\hline 30. & Faculty of Philology & Fac_30 & SSH & 0.17 & 0.18 & 1.06 \\
\hline 31. & Faculty of Philosophy & Fac_31 & SSH & 0.06 & 0.11 & 1.74 \\
\hline
\end{tabular}

Faculty of Technology and Metallurgy, as the only representative from the group of Technology and Engineering Sciences.
One of the advantages of using PROMETHEE II method is the possibility of graphic interpretation with the assistance of 
Table 6. The results of PROMETHEE II final ranking

\begin{tabular}{|c|c|c|c|c|c|c|c|}
\hline Rank & Name of Faculty & $\begin{array}{l}\text { Faculty label in } \\
\text { PROMETHEE } \\
\text { model }\end{array}$ & Scientific field & $\Phi$ & $\Phi^{+}$ & $\Phi^{-}$ & Cluster* \\
\hline 1. & Faculty of Physical Chemistry & Fac_3 & SM & 0.8590 & 0.8617 & 0.0027 & \multirow{8}{*}{ A } \\
\hline 2. & $\begin{array}{l}\text { Faculty of Technology and } \\
\text { Metallurgy }\end{array}$ & Fac_4 & TES & 0.7971 & 0.8051 & 0.0080 & \\
\hline 3. & Faculty of Chemistry & Fac_1 & SM & 0.7405 & 0.7663 & 0.0258 & \\
\hline 4. & Faculty of Medicine & Fac_7 & MS & 0.7397 & 0.7671 & 0.0274 & \\
\hline 5. & Faculty of Physics & Fac_10 & SM & 0.6880 & 0.7461 & 0.0582 & \\
\hline 6. & Faculty of Pharmacy & Fac_5 & MS & 0.6160 & 0.6818 & 0.0658 & \\
\hline 7. & Faculty of Biology & Fac_2 & SM & 0.5966 & 0.6679 & 0.0713 & \\
\hline 8. & Faculty of Mathematics & Fac_14 & SM & 0.5183 & 0.6548 & 0.1365 & \\
\hline 9. & $\begin{array}{l}\text { Faculty of Organizational } \\
\text { Sciences }\end{array}$ & Fac_13 & TES & 0.2856 & 0.4964 & 0.2108 & \multirow{6}{*}{ B } \\
\hline 10. & Technical Faculty in Bor & Fac_9 & TES & 0.1967 & 0.4443 & 0.2476 & \\
\hline 11. & $\begin{array}{l}\text { Faculty of Electrical } \\
\text { Engineering }\end{array}$ & Fac_8 & TES & 0.1577 & 0.4269 & 0.2693 & \\
\hline 12. & Faculty of Forestry & Fac_17 & TES & 0.1273 & 0.4142 & 0.2869 & \\
\hline 13. & $\begin{array}{l}\text { Faculty of Mining and } \\
\text { Geology }\end{array}$ & Fac_15 & TES & 0.1246 & 0.4051 & 0.2805 & \\
\hline 14. & $\begin{array}{l}\text { Faculty of Mechanical } \\
\text { Engineering }\end{array}$ & Fac_12 & TES & 0.0685 & 0.3766 & 0.3081 & \\
\hline 15. & $\begin{array}{l}\text { Faculty of Sport and Physical } \\
\text { Education }\end{array}$ & Fac_22 & $\mathrm{SSH}$ & 0.0512 & 0.4000 & 0.3488 & \multirow{6}{*}{$\mathrm{C}$} \\
\hline 16. & Faculty of Civil Engineering & Fac_18 & TES & -0.0673 & 0.3163 & 0.3836 & \\
\hline 17. & $\begin{array}{l}\text { Faculty of Veterinary } \\
\text { Medicine }\end{array}$ & Fac_16 & MS & -0.0922 & 0.3072 & 0.3994 & \\
\hline 18. & $\begin{array}{l}\text { Faculty of Transport and } \\
\text { Traffic Engineering }\end{array}$ & Fac_11 & TES & -0.1269 & 0.3164 & 0.4433 & \\
\hline 19. & Faculty of Geography & Fac_19 & SM & -0.1636 & 0.2851 & 0.4487 & \\
\hline 20. & Faculty of Agriculture & Fac_6 & TES & -0.1864 & 0.3216 & 0.5079 & \\
\hline 21. & Faculty of Security Studies & Fac_25 & SSH & -0.2403 & 0.2635 & 0.5038 & \multirow{11}{*}{$\mathrm{D}$} \\
\hline 22. & Faculty of Philosophy & Fac_31 & SSH & -0.2440 & 0.2814 & 0.5254 & \\
\hline 23. & Faculty of Economics & Fac_23 & SSH & -0.3260 & 0.2262 & 0.5522 & \\
\hline 24. & $\begin{array}{l}\text { Faculty for Special Education } \\
\text { and Rehabilitation }\end{array}$ & Fac $\_21$ & $\mathrm{SSH}$ & -0.3280 & 0.2326 & 0.5606 & \\
\hline 25. & Faculty of Architecture & Fac_24 & TES & -0.3375 & 0.2176 & 0.5551 & \\
\hline 26. & Faculty of Philology & Fac_30 & SSH & -0.4470 & 0.1614 & 0.6084 & \\
\hline 27. & Faculty of Dental Medicine & Fac_20 & MS & -0.5685 & 0.1729 & 0.7414 & \\
\hline 28. & Faculty of Political Sciences & Fac_26 & SSH & -0.7190 & 0.1162 & 0.8351 & \\
\hline 29. & Teacher Education Faculty & Fac $\_27$ & SSH & -0.8487 & 0.0629 & 0.9116 & \\
\hline 30. & Faculty of Orthodox Theology & Fac_29 & SSH & -0.9232 & 0.0178 & 0.9410 & \\
\hline 31. & Faculty of Low & Fac_28 & $\mathrm{SSH}$ & -0.9480 & 0.0111 & 0.9591 & \\
\hline
\end{tabular}

*In column Cluster faculties are grouped in 4 clusters $(A, B, C, D)$ in accordance with the GAIA plan, presented in Figure 4 
GAIA plane (Brans \& Mareschal, 1994). The aim of GAIA plane is to give $2 \mathrm{D}$ or $3 \mathrm{D}$ presentation of preferences of the decision makers in respect to each considered alternative in the model. Criteria in GAIA plane are presented as vectors, while the alternatives are shown with corresponding points, where the distance of these points from the center of GAIA plane, as well as their positioning in relation to the most important criteria in the model, determines their priority during GAIA ranking. In addition, the length of each criteria vector determines the criteria "ability" to make the differentiation between the alternatives, where the longer a criterion vector is in the GAIA plane, it has the more discriminating power.

It is possible in GAIA plane to design vector weight criteria, whereby this vector is called a decision stick pi. In this way, the decision maker in this analysis can have relevant information on the aspects of conflicting criteria, as well as on the impact of the weight criteria on the final decision (Figure 4).

\section{DISCUSSION}

Based on the GAIA plane and 2D presentation (U-V axis reference plane view) for the given model of ranking of faculties, which is shown in Figure 4, it can be concluded that 4 clusters could be extracted, which include 31 faculties of UB from 4 scientific fields ( SM, MS, SSH, and TES). Cluster A, in Figure 4, consists of 8 faculties, which were previously best ranked using the PROMETHEE II complete ranking (see

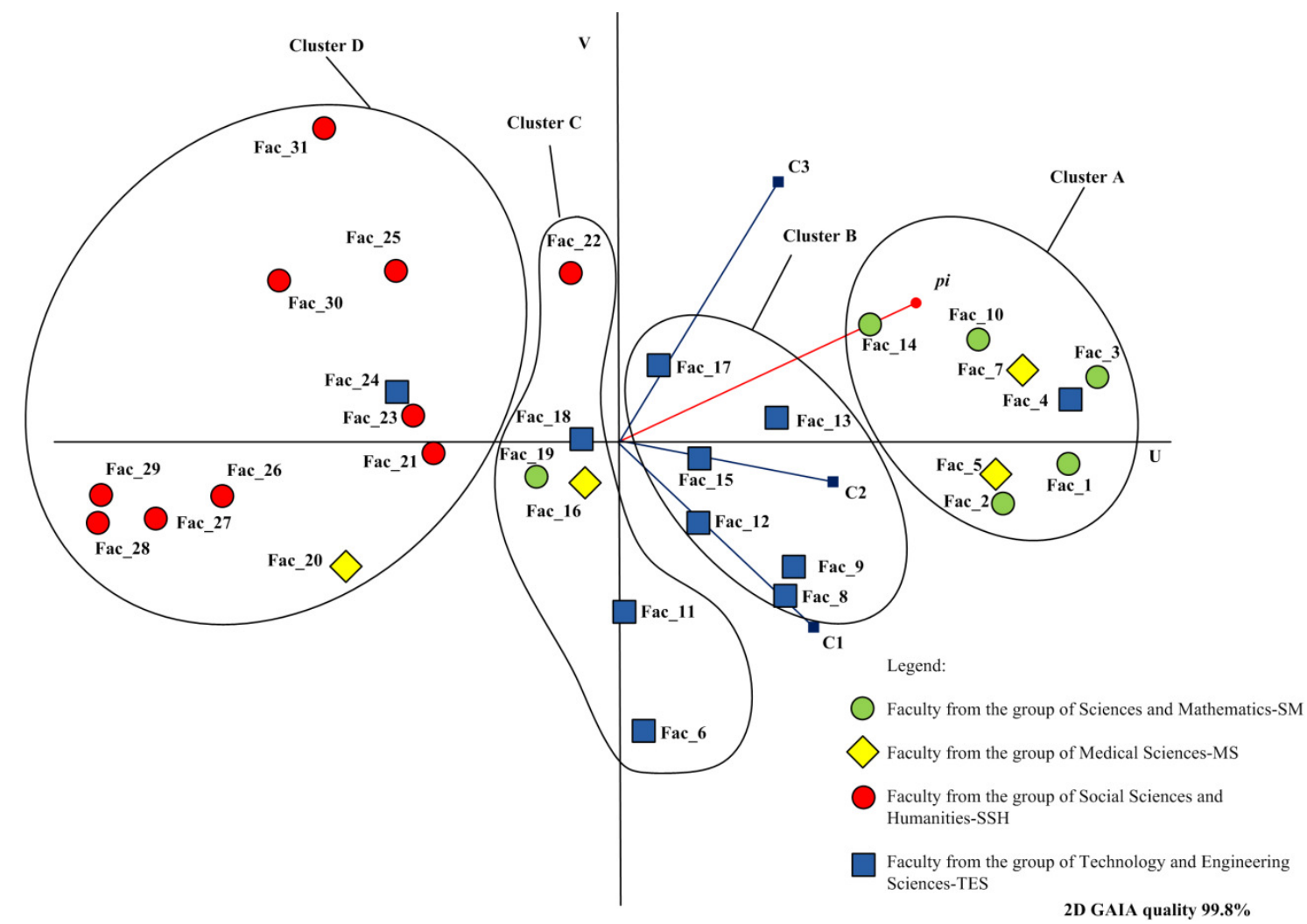

Figure 4. The GAIA plane 
Table 6). Within this cluster can be distinguished group of 5 faculties can be distinguished (FPhyChe-Fac_3, FTMFac_4, FM- Fac_7, FPhys - Fac_10 FMathFac_14), whose performance (a high ranking position) can be explained with the best ratio of the number of citations to the number of papers, and in Figure 4 their position and proximity in relation to this criterion $\mathrm{C} 3$ in the model is evident. As for the remaining three faculties from cluster A (FCh- Fac_1, FB-Fac_2 FPh-Fac_5), their belonging to a group of best faculties can be attributed to good results in relation to the criteria $\mathrm{C} 1$ and $\mathrm{C} 2$ in the model.

The second cluster B consists of 6 faculties from the group of Technology and Engineering Sciences (FOS-Fac_13, TFBFac_9, FEEng - Fac_8, FF-Fac_17, FMGFac_15, FMEng-Fac_12).

The third cluster $\mathrm{C}$, consists of faculties with lower achieved results according to all three criteria in the model, which can be determined based on their position in the GAIA plane. What's more, these 6 faculties (FAg -Fac_6, FTTEng- Fac_11, FCEngFac_18, FVM-Fac_16, FGeo - Fac_19 and FSPE-Fac_22) are located in positions with apparent distance from the direction of all three vectors criteria but much closer to the center of GAIA plane compared to the group of faculties from cluster D, which includes faculties with significantly weaker results of the publication of papers in journals with SCIe and SSCI compared to the previous three clusters of faculties respectively (A, B and $\mathrm{C}$ ).

Regarding the cluster $\mathrm{D}$, this cluster consists of UB faculties, which have a significantly weaker achieved results in publishing papers in journals indexed in SCIe and SSCI according to the criteria considered in this model, so their position in
GAIA plane is such that they are positioned opposite of vectors of all three criteria and significantly away from the center of GAIA plane. In this cluster together with 9 faculties from the group Social Science and Humanities, there are also two more faculties, one from the group Technology and Engineering Sciences (FAr- Fac 24) and FDM- Fac_20 from group of Medical Sciences.

\section{CONCLUSIONS}

Although the first faculty ranking appeared almost 10 years ago, the methodology is still not fully developed. There are some deficiencies in the current methodology, depending on which of the criteria researcher consider important for evaluating scientific research. As a result, there are different ranking lists of universities, which are different in many ways. Future research should go in the direction to establish a uniform methodology of ranking of higher education institutions.

In this paper authors attempted to overcome some of the limitations of current methodologies, primarily the size of the faculty and the different areas of research, whit respect to each individual group of faculty. The achieved improvements that are evident in the last few years at most discussed faculties of UB, indicate that the process of approaching the Shanghai list started with certain resistance of part of the University which do not react to the fact that changes have already become part of reality. Defined clusters point to a particular group of faculty who are more sensitive to changes and those who are less sensitive.

The results obtained in this study indicate that the impact of certain faculties to the 
overall position of UB on ARWU list is different regarding the scientific field. Given that the main criteria used for ranking the impact of certain faculties is the same as the ranking of the university on ARWU list, such as: papers published in journals indexed in SCIe and SSCI lists and the number of citations, it is evident that at many faculties of UB have not built a practice for publications of this kind, which resulted in the fact that in these groups, but also at individual faculties within the same group at the UB, specific criteria for promotion of a researcher, for doctoral dissertation, for mentoring and more, were defined.

In the analyzed period big improvements can be seen, regarding the results achieved by the studied criteria, at many faculties of UB. In order to continuously improve the quality of scientific work at UB, by introducing the same standards also in the field of social sciences and humanities as in other three fields of science, it is realistic to expect that in the future period UB can be found among the first 100 universities on ARWU list.

\section{References}

Altanopoulou, P., Dontsidou M., \& Tselios, N. (2012). Evaluation of ninetythree major Greek university departments using Google Scholar. Quality in higher

\title{
УНИВЕРЗИТЕТ У БЕОГРАДУ НА “ARWU" LISTИ - ДЕО I: АНАЛИЗА УТИЦАЈ ПОЈЕДИНАЧНИХ ФАКУЛТЕТА НА ДОСТИГНУТУ ПОЗИЦИЈУ ПРИМЕНОМ "PROMETHEE-GAIA" МЕТОДЕ
}

\author{
Живан Живковић, Милица Арсић, Ђорђе Николић
}

\section{Извод}

Још од 2012. године, Универзитет у Београду (УБ) је рангиран међу 500 најбољих универзитета у свету, на престижној листи Академског Рангирања Светских Универзитета (“ARWU”), која је такође позната и као Шангајска листа. Ових 500 универзитета представљају свега $2 \%$ укупног броја универзитета на свету. Према најновијем глобалном рангирању, спроведеном 2015. године, УБ је рангиран између 201-ог и 300-тог места, и најбоље је рангиран универзитет у региону Југоисточне Европе.

УБ се састоји од 31 факултета и 11 истраживачких института и свака од ових институција, на свој начин доприноси укупно достигнутој позицији УБ на овој листи. Овај рад анализира утицај појединачних факултета на позицију на којој се рангира УБ на "ARWU” листи, преко броја радова индексираних у "Science Citation Index - SCIe" и "SSCI", узимајући у обзир број цитата и број цитата по раду и по истраживачу за период 2011 - 2015. За обраду података коришћена је метода вишекритеријумског одлучивања "PROMETHEE-GAIA". Добијени резултати су издвојили четири кластера факултета, где спадају: факултети са највећим утицајем, факултети са значајним утицајем, са средњим и ниским утицајем на укупне резултате рангирања на “ARWU” листи.

Кључне речи: Рангирање факултета, Универзитет у Београду, “ARWU” листа, "PROMETHEE - GAIA" метода. 
education, 18 (1), 111-137.

Arsić, M., Milijić, N., Živković, D., Nikolić, Đ., \& Živković, Ž. (2012). The analysis of scientific - research work of group of technical faculties of Belgrade University in the post-accredation period. Serbian Journal of Management, 7 (1), 9-24.

Behzadian, M., Kazemzadeh, R.B., Albadvi, A., \& Aghdasi, M. (2010). PROMETHEE: a comprehensive literature review on methodologies and applications. European Journal of Operational Research, 200 (1), 198-215.

Brans, J.P., \& Mareschal, B. (1994). The PROMCALC \& GAIA decision support system for multicriteria decision aid. Decision Support Systems, 12 (4-5), 297-310.

Brans, J.P., \& Vincke, Ph. (1985). A preference ranking organisation method: The PROMETHEE method for MCDM. Management Science, 31 (6), 647-656.

Brans, J.P., Mareschal, B., \& Vincke, Ph. (1984). PROMETHEE: A new family of outranking methods in multi-criteria analysis. In J. P. Brans (Ed.), Operational research '84 (pp. 477-490). North-Holland, Amsterdam.

Brew, A., \& Boud, D. (1995). Teaching and research: establishing the vital link with learning. Higher Education, 29 (3), 261-273.

Chou, C.P., Lin, H., \& Chiu, Y. (2013). The impact of SSCI and SCI Taiwan's academy: an outcry for fair play. Asia Pacific Education Review, 14 (1), 23-31.

Daraio, C., Bonaccorsi, A., \& Simar, L. (2015). Rankings and university performance: A conditional multidimensional approach. European Journal of Operational Research, 224 (3), 918-930.

Docampo, D. (2013). Reproducibility of the Shanghai academic ranking of world universities. Scientometrics, 94 (2), 567-587.

Abramo, G., Cicero, T., \& D'Angelo, C.A. (2013). The impact of unproductive and top researchers on overall university research performance. Journal of Informetrics, 7 (1), 166-175.

Ishizaka, A., \& Nemery, P. (2011). Selecting the best statistical distribution with PROMETHEE and GAIA. Computers \& Industrial Engineering, 61 (4), 958-969.

Lin, C.S., Hsuan, M.H., \& Chen, D.Z. (2013). The influences of counting methods on university rankings based on paper count and citation count. Journal of Informetrics, 7 (3), 611-621.

Macharis, C., Springael, J., De Brucker, K., \& Verbeke, A. (2004). PROMETHEE and AHP: The design of operational synergies in multicriteria analysis. Strengthening PROMETHEE with ideas of AHP. European Journal of Operational Research, 153 (2), 307-317.

Metcalf, M., Stocks, K., Summers, S.L., \& Wood, D.A. (2015). Citation-based accounting education publication rankings. Journal of Accounting Education, 33 (4), 294-308.

Millot, B. (2015). International rankings: Universities vs. higher education systems. International Journal of Educational Development, 40, 156-165.

Olcay, G.A., \& Bulu, M. (2016). Is measuring the knowledge creation of universities possible? A review of university rankings. Technological Forecasting \& Social Change, Article in press.

Price, J., \& Cotten, S.R. (2006). Teaching, research, and service: Expectations of assistant professors. The American sociologist, 37 (1), 5-21.

Saarela, M., Karkkainen, T., Lahtonen, T., \& Rossi, T. (2016). Expert-based versus citation based ranking of scholarly and 
scientific publication channels. Journal of Informetrics, 10 (3), 693-718.

Sidorenko, T., \& Gorbatova, T. (2015). Efficiency of Russian education through the scale of World University Rankings. Procedia - Social and Behavioral Sciences, 166, 464-467.

Da Silva, R., Lamb, L.C., \& Barbosa, M.C. (2016). University, correlations and rankings in the Brazilian universities national admission examinations. Physica A, 457, 295-306.

Vego G., Kučar-Dragičević, S., \& Koprivanac, N. (2008). Application of multicriteria decision-making on strategic municipal solid waste management in Dalmatia, Croatia. Waste Management, 28, 2192-2201.

Wijetunge, P. (2002). Adoption of knowledge management by the Sri Lankan University librarians in the light of the National Policy on University Education. International Journal of Educational Development , 22, 85-94.

Zornić, N., Marković, A., \& Jeremić, V. (2014). How the top 500 ARWU can provide a misleading rank. Journal of Association for Information Science and Technology, 65 (6), 1303-1304. 